\title{
Implementasi RFID Mobile untuk Alat Pembayaran dan Pengontrol Keuangan Santri
}

\author{
Tholib Hariono $^{1}$, Hilyah Ashoumi ${ }^{2}$ \\ ${ }^{1}$ Fakultas Teknologi Informasi, Universitas KH. A. Wahab Hasbullah Jombang \\ ${ }^{2}$ Fakultas Agama Islam, Universitas KH. A. Wahab Hasbullah Jombang \\ Email : ${ }^{1}$ hariono@unwaha.ac.id, ${ }^{2}$ hira@unwaha.ac.id
}

\begin{tabular}{|c|c|}
\hline Info Artikel : & Abstract \\
\hline $\begin{array}{c}\text { Sejarah artikel } \\
\text { Menerima : } \\
3 \text { Oktober } 2020 \\
\text { Revisi : } \\
10 \text { Oktober } 2020 \\
\text { Diterima : } \\
15 \text { Oktober } 2020 \\
\text { Online : } \\
19 \text { Oktober } 2020\end{array}$ & $\begin{array}{l}\text { The Islamic boarding school is a place for students to gain religious } \\
\text { knowledge. The Santri period is the first time for most students to fully } \\
\text { finance independently without parental supervision. Many students are } \\
\text { unable to help financially so that they are increasingly irrational in buying } \\
\text { their needs, the money charts in a short time after being sent money by their } \\
\text { parents. One of the negative impacts of uncontrolled impact is the tendency } \\
\text { of students to inform money when they know money. This research } \\
\text { implements RFID as a payment instrument for students in the Islamic } \\
\text { boarding school environment, through this payment system all santri } \\
\text { financial data can manage the good expenses owned by these students. RFID } \\
\text { is used for several processes or needs, namely checking balances, changing } \\
\text { pins and processing payments. The results of RFID testing show a fast time } \\
\text { in each process, namely the balance check process which takes an average } \\
\text { of } 1.55 \text { seconds, the process of changing pin numbers on an average of } 10.05 \\
\text { seconds, the payment process takes an average of } 4.675 \text { seconds. }\end{array}$ \\
\hline $\begin{array}{l}\text { Keyword : } \\
\text { rfid, santri, } \\
\text { financial }\end{array}$ & Intisari \\
\hline $\begin{array}{c}\text { Kata Kunci : } \\
\text { rfid, santri, } \\
\text { keuangan }\end{array}$ & $\begin{array}{l}\text { Pesantren merupakan tempat para santri untuk menimba ilmu agama Islam. } \\
\text { Masa Santri adalah saat pertama bagi sebagian besar peserta didik untuk } \\
\text { mengelola keuangan secara mandiri tanpa pengawasan penuh dari orang } \\
\text { tua. Banyak santri yang tidak dapat mengatur keuangannya sehingga } \\
\text { semakin tidak rasionalnya dalam membeli kebutuhannya, seringkali santri } \\
\text { kehabisan uang dalam waktu singkat setelah dikirimi uang oleh orang } \\
\text { tuanya. Salah satu dampak negatif keuangan yang tidak terkontrol adalah } \\
\text { kecenderungan santri untuk mencuri uang temannya pada saat kehabisan } \\
\text { uang. Penelitian ini mengimplementasikan RFID untuk alat pembayaran } \\
\text { santri di lingkungan pondok pesantren, melalui sistem pembayaran ini } \\
\text { seluruh data keuangan santri dapat dikontrol penggunaannya baik } \\
\text { pengeluaran maupun saldo yang dimiliki oleh santri tersebut. RFID } \\
\text { digunakan untuk beberapa proses atau kebutuhan yaitu cek saldo, } \\
\text { pergantian pin dan proses pembayaran. Hasil pengujian RFID menunjukkan } \\
\text { waktu yang cepatpada setiap prosesnya yaitu pada proses cek saldo yang rata-rata } \\
\text { membutuhkan waktu } 1.55 \text { detik, proses pergantian pin rata-rata } 10.05 \text { detik proses } \\
\text { pembayaran membutuhkan waktu rata-rata } 4.675 \text { detik. }\end{array}$ \\
\hline
\end{tabular}




\section{Latar Belakang}

Pesantren merupakan tempat para santri untuk menimba ilmu agama Islam. Masa Santri adalah saat pertama bagi sebagian besar peserta didik untuk mengelola keuangan secara mandiri tanpa pengawasan penuh dari orang tua. Mereka harus belajar untuk mandiri secara finansial dan bertanggungjawab atas keputusan yang mereka buat. Pada dasarnya, dimasa inilah seorang santri menunjukkan sifat asli perilaku ekonominya. Banyak santri yang tidak dapat mengatur keuangannya sehingga semakin tidak rasionalnya dalam membeli kebutuhannya, seringkali santri kehabisan uang dalam waktu singkat setelah dikirimi uang oleh orang tuanya. Karena jarak yang jauh sebagian besar orang tua tidak mampu mengontrol keuangan putra putrinya, begitu juga pengurus pondok tanpa adanya dukungan sistem tidak mampu mengontrol kondisi keuangan para santrinya. Salah satu dampak negatif keuangan yang tidak terkontrol adalah kecenderungan santri untuk mencuri uang temannya pada saat kehabisan uang. Untuk mengantisipasi hal tersebut diperlukan peranan teknologi informasi yang dapat memudahkan dalam mengontrol dan monitoring kondisi keuangan santri oleh orang tua dan pengurus pondok, salah satunya dengan memanfaatkan RFID pada sistem transaksi. Teknologi ini dapat dimanfaatkan layaknya kartu ATM, yang dapat digunakan untuk transaksi, baik untuk mengambil uang tunai maupun belanja di tempat yang terintegrasi sistem tersebut. Penerapan teknologi RFID pada penelitian ini akan dikombinasikan dengan android mobile beserta sensor reader yang akan mengambil informasi pada tag RFID. Informasi tersebut kemudian dikirim ke server database dengan metode web api untuk melakukan proses update saldo, informasi saldo, informasi customer dan lain-lain. Melalui pemanfaatan teknologi mobile, perancangan sistem ini juga menerapkan personal identification number (PIN) pada setiap transaksi sebagai security untuk menjaga keamanan data customer.

Tujuan penelitian ini adalah membangun software untuk mempermudah mengontrol dan memonitoring keuangan santri secara realtime oleh orang tua maupun pihak pesantren dengan mengimplementasikan teknologi RFID berbasis mobile sebagai sarana transaksinya.

\section{KAJIAN TEORI}

\subsection{Telegram Bot Api}

\section{Teknologi RFID (Radio Frequency Identification Device)}

Definisi menurut (Maryono, 2005) identifikasi dengan frekuensi radio adalah teknologi untuk mengidentifikasi seseorang atau objek benda menggunakan transmisi frekuensi radio, khususnya $125 \mathrm{kHz}$, 13.65Mhz atau $800-900 \mathrm{MHz}$. RFID menggunakan komunikasi gelombang radio untuk secara unik mengidentifikasi objek atau seseorang terdapat beberapa pengertian RFID menurut (Maryono, 2005) yaitu : a. RFID (Radio Frequency Identification) adalah sebuah metode identifikasi dengan menggunakan sarana yang disebut label RFID atau transponder (tag) untuk menyimpan dan mengambil data jarak jauh. B. Label atau transponder (tag) adalah sebuah benda yang bisa dipasang atau dimasukkan di dalam sebuah produk, hewan atau bahkan manusia dengan tujuan untuk identifikasi menggunakan gelombang radio. Label RFID terdiri atas mikrochip silikon dan antenna.

Teknologi RFID ini dapat digunakan pada sistem yang dapat melakukan pelacakan makanan yang mudah rusak dalam rantai pasokan dengan cara menyimpan data dalam memori tag dan reader RFID kemudian mengambil data tag dan mentransfernya ke database back-end untuk diakses dari jarak jauh dalam pemantauan kondisi objek/makanan (Duroc dan Tedjini, 2018).

\section{RFID Tag}

Tag RFID dapat berupa stiker, kertas atau plastik dengan beragam ukuran. Di dalam setiap tag ini terdapat chip yang mampu menyimpan sejumlah informasi tertentu. Memori pada tag secara dibagi menjadi sel-sel. Beberapa sel menyimpan data Read Only, misalnya serial number yang unik yang disimpan pada saat tag tersebut diproduksi. Selain pada RFID mungkin juga dapat ditulis dan dibaca secara berulang. Sebuah tag RFID atau transponder, terdiri atas sebuah mikro (microchip) dan sebuah sistem. Chip mikro itu sendiri dapat berukuran sekecil butiran pasir, seukuran $0.4 \mathrm{~mm}$. Chip tersebut menyimpan nomor seri yang unik atau informasi lainnya tergantung kepada tipe memorinya. Tipe memori itu sendiri dapat read- 8 only, read-write, atau writeonceread-many. Antena yang terpasang pada chip mikro mengirimkan informasi dari chip ke reader. Biasanya rentang pembacaan diindikasikan dengan besarnya sistem. Antena yang lebih 
besar mengindikasikan rentang pembacaan yang lebih jauh. Tag tersebut terpasang atau tertanam dalam obyek yang akan diidentifikasi. Tag dapat discan dengan reader bergerak maupun stasioner menggunakan gelombang radio.

Berdasarkan catu daya tag, tag RFID dapat digolongkan menjadi :

1. Tag Aktif: yaitu tag yang catu dayanya diperoleh dari baterai, sehingga akan mengurangi daya yang diperlukan oleh pembaca RFID dan tag dapat mengirimkan informasi dalam jarak yang lebih jauh. Kelemahan dari tipe tag ini adalah harganya yang mahal dan ukurannya yang lebih besar karena lebih komplek. Semakin banyak fungsi yang dapat dilakukan oleh tag RFID maka rangkaiannya akan semakin komplek dan ukurannya akan semakin besar.

2. Tag Pasif: yaitu tag yang catu dayanya diperoleh dari medan yang dihasilkan oleh pembaca RFID. Rangkaiannya lebih sederhana, harganya jauh lebih murah, ukurannya kecil, dan lebih ringan. Kelemahannya adalah tag hanya dapat mengirimkan informasi dalam jarak yang dekat dan pembaca RFID harus menyediakan daya tambahan untuk tag RFID. Tag RFID ini digadang-gadang sebagai pengganti barcode pada masa yang akan datang.

\section{Reader RFID}

Terminal Reader RFID, terdiri atas RFID reader dan antena yang akan mempengaruhi jarak optimal identifikasi. Terminal RFID akan membaca atau mengubah informasi yang tersimpan di dalam tag melalui frekuensi radio. Terminal RFID terhubung langsung dengan sistem Host Komputer maupun mobile devices.

\section{METODE PENELITIAN DAN PERANCANGAN SISTEM}

\subsection{Metode Penelitian}

Metode dalam penelitian ini menggunakan model penelitian pengembangan atau Research and

Development (R\&D) dengan tahapan sebagai berikut :

3.1.1 Penelitian dan Pengumpulan Data dengan melakukan studi literatur dan studi lapangan. Pada studi literatur, digunakan untuk menemukan konsep maupun tutorial yang berkaitan dengan perkembangan teknologi RFID. Selain studi literatur, dilakukan pula studi lapangan ke beberapa ribath dalam naungan pondok pesantren Bahrul Ulum Tambakberas Jombang. Studi lapangan ini digunakan untuk menggali informasi tentang bagaimana penerapan manajemen keuangan santri yang berjalan, kekurangan dan kelebihan dari sistem yang telah berjalan serta kemampuan sumber daya di dalamnya,

3.1.2 Perencanaan dengan merumuskan permasalahan, menentukan tujuan, mendata produk yang dihasilkan develop preliminary form of product, yaitu mengembangkan bentuk permulaan dari produk yang akan dihasilkan berupa monitoring keuangan santri melalui penggunaan teknologi RFID pada setiap transaksi. Penulis dalam membuat rancang bangun sistem akan menggunakan metode prototype untuk pengembangan perangkat lunak dengan tahapan 1) Analisis/penyelidikan yaitu mempelajari dan menganalisa hasil informasi yang diperoleh dari pengumpulan data terutama pada kemungkinan perubahan alur keuangan yang sedang berjalan serta ketercukupan kebutuhan sumber daya yang ada di dalamnya. Hasil tahap ini diperoleh gambaran sementara alur dari sistem yang akan dibuat. 2) Analisis/Desain yaitu melakukan proses pengembangan aplikasi dengan membuat rancangan alur sistem, pihak/user yang terlibat, rancangan database, rancangan antarmuka, sistem jaringan dan rancangan transaksi melalui RFID. 3) Desain/Implementasi yaitu hasil desain software dilakukan pengujian secara prototipe, dievaluasi, dan dimodifikasi berulangulang untuk meminimalisir bug yang terjadi serta pemakai akhir dapat menerimanya dan 4) Implementasi/pemeliharaan pada sistem/software yang telah dibuat agar dapat digunakan dan dimodifikasi dengan mudah karena sebagian besar dokumentasi sistem disimpan dalam disk.

3.1.3 Preliminary field testing, yaitu melakukan uji coba awal perangkat lunak secara terbatas dalam skala terbatas. Uji coba dilakukan dengan menggunakan metode uji Blackbox dan Whitebox. Pengujian ini meliputi beberapa aspek diantaranya penginputan data santri, data mitra/toko, proses transaksi melalui RFID, cek saldo, update pin dan proses input setoran dari orang tua. 
3.1.4 Main product revision, Tahapan ini merupakan perbaikan dari hasil uji coba lapangan awal. Pada tahap penyempurnaan produk awal ini, lebih banyak dilakukan dengan pendekatan kualitatif produk yaitu dengan menerima masukan dari pihak pesantren.

\subsection{Perancangan Sistem}

\subsubsection{Perancangan alur sistem}

Perancangan Sistem ini dibuat berdasarkan hasil observasi dan wawancara ke tempat penelitian.

Hasil perancangan sistem adalah sebagai berikut :

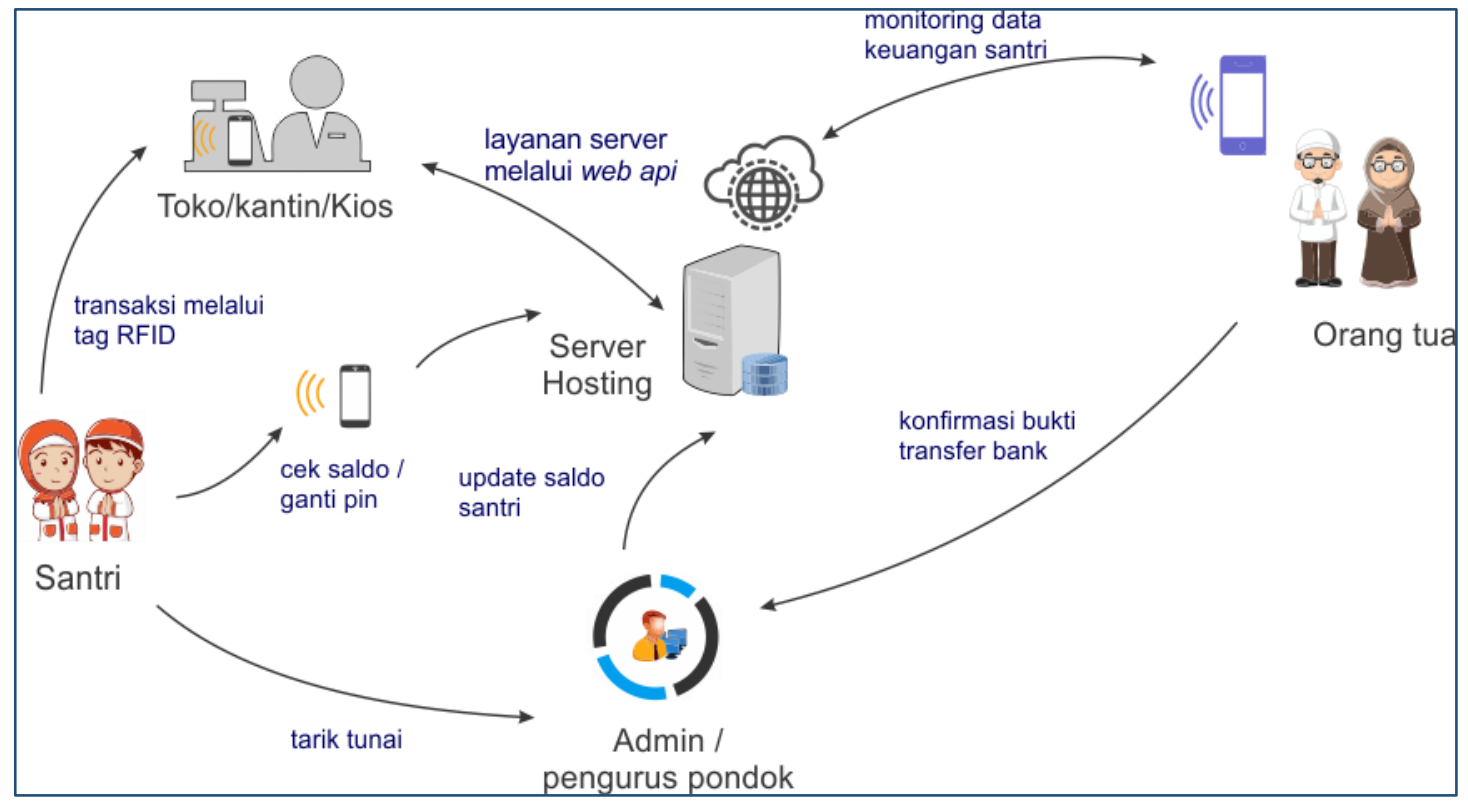

Gambar 1: Diagram alur umum perancangan sistem pembayaran dan pengontrol keuangan santri berbasis RFID

Dari perancangan alur pada gambar 1 dapat dijelaskan bahwa sistem melibatkan empat aktor yaitu santri, orang tua, toko/kios dan admin (pengurus pondok). Setiap santri akan mendapatkan tag RFID yang berbentuk seperti kartu ATM. Kartu tersebut digunakan untuk transaksi di toko/kios/kantin di lingkungan pondok pesantren yang telah terintegrasi dengan sistem.

Santri yang berbelanja dengan toko / mitra dari pondok pesantren dapat melakukan transaksi melalui tapping kartu RFID ke reader yang ada pada smartphone. Setelah melakukan tapping kartu RFID ke smartphone sistem akan melakukan verifikasi dan update saldo rekening santri maupun rekening pemilik toko. Selain transaksi melalui kartu RFID santri dapat melakukan cek saldo maupun pergantian PIN untuk menjaga keamanan akun. Untuk beberapa kebutuhan yang harus menggunakan uang tunai santri dapat melakukan penarikan tunai ke pengurus pesantren yang ditunjuk.

Orang tua santri yang ada di rumah dapat melakukan monitoring penggunaan uang oleh putra-putrinya. Laporan keuangan menyajikan detail dan rekap transaksi bulanan. Selain itu untuk melakukan setoran kepada santri orang tua dapat melakukan transfer ke rekening pesantren dan upload bukti transfer tersebut di menu yang telah disediakan aplikasi. Untuk memudahkan upload bukti pada berita acara diikut sertakan nomor rekening santri.

Toko / mitra adalah unit usaha yang bekerja sama dengan pihak pesantren agar dalam setiap transaksi dengan santri proses pembayaran dilakukan melalui sistem tapping RFID. Setiap transaksi yang masuk akan dicairkan oleh pihak admin pesantren melalui transfer antar bank pada rekening yang telah didaftarkan sebelumnya pada sistem. 
Admin / pengurus pondok memiliki kendali penuh atas data santri data toko / mitra. Admin bertugas menambahkan data santri beserta orang tua dan data toko / mitra. Selain itu admin dapat melakukan pemblokiran rekening santri maupun rekening toko ketika dianggap melakukan pelanggaran.

\subsubsection{Perancangan Alur Transaksi Pembayaran Melalui Kartu RFID}

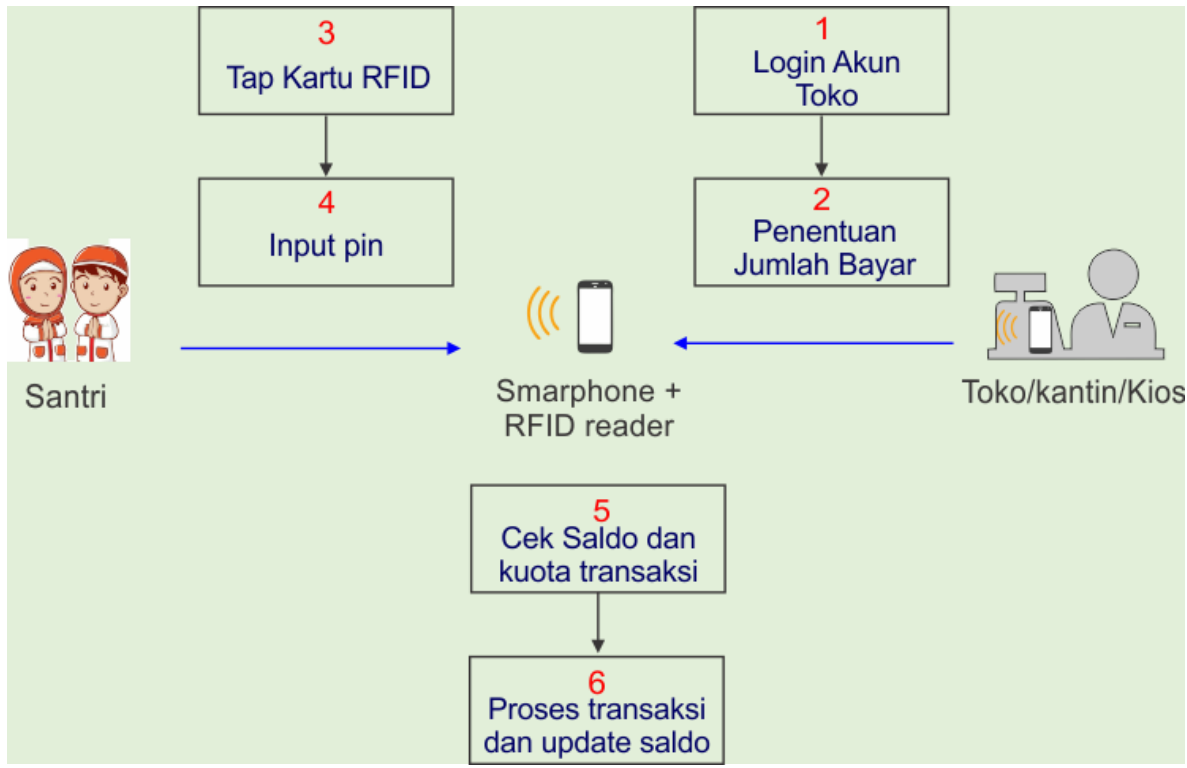

Gambar 2: Diagram alur umum perancangan sistem pembayaran dan pengontrol keuangan santri berbasis RFID

Proses transaksi dilakukan dengan pihak toko melalui smartphone menginputkan jumlah yang akan dibayar, kemudian santri melakukan tapping kartu RFID ke smartphone lalu menginputkan pin dan proses submit. Hasil submit akan direspon oleh server dengan memverifikasi kode pada tag RFID dan pin yang diinputkan ketika transaksi, hasilnya akan ditampilkan pada layar smartphone. Selain melakukan transaksi pembelian, customer (santri) dapat melakukan cek saldo dan menarik uang tunai untuk keperluan transaksi luar, seluruh pengeluaran santri baik melalui transaksi RFID maupun tarik tunai dapat diatur batas maksimalnya sesuai aturan pondok, hal ini untuk mencegah pemborosan penggunaan uang oleh santri. Pada sisi orang tua dapat melakukan monitoring keuangan putra-putrinya. Informasi yang diperoleh berupa saldo keuangan, transaksi keluar dan transaksi masuk. Melalui informasi ini orang tua dapat menentukan kapan melakukan pengiriman uang kepada putra-putrinya yang ada di pondok. Pengiriman uang dilakukan melalui transfer ke rekening pondok pesantren dan bukti diupload di sistem untuk diverifikasi oleh admin. Hasil verifikasi admin akan ditambahkan ke saldo rekening santri.

\section{Implementasi dan Pembahasan}

\subsection{Implementasi}

Implementasi dan pembahasan ini akan menyajikan hasil perancangan sistem yang telah dibuat. Sistem yang telah dibuat berupa software berbasis web yang dikembangkan menggunakan framework codeigniter dan software berbasis mobile yang dikembangkan menggunakan android studio.

1. Halaman login admin 


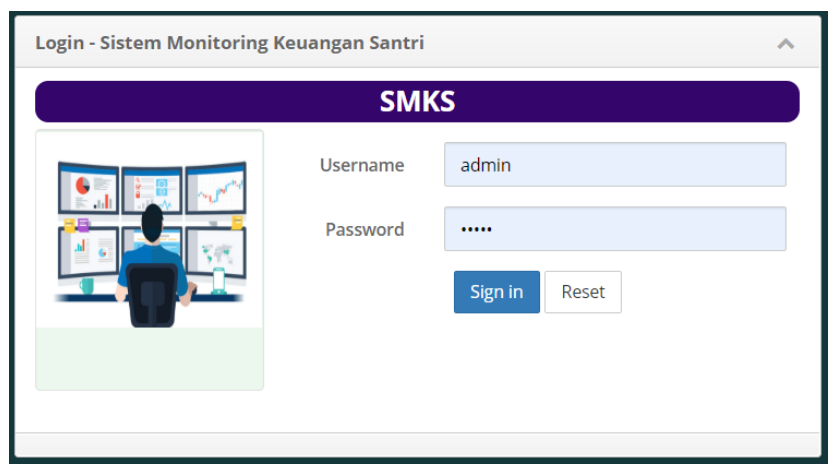

Gambar 3 : Tampilan halaman login admin

Halaman login digunakan untuk autentifikasi user admin pada sistem monitoring keuangan santri melalui input username dan password dan klik tombol Sign in.

\section{Halaman Data Santri}

Halaman data santri digunakan untuk menambah, edit, hapus serta menampilkan data santri. Data ini merupakan data master yang harus diisi di awal dalam menggunakan siste ini. Point penting pada halaman ini adalah menampilkan data nama, no rekening, saldo dan status santri. Pengisian data ini dilakukan oleh pihak admin dari pihak pondok pesantren. Tampilan halaman ini dapat dilihat pada gambar 4 .

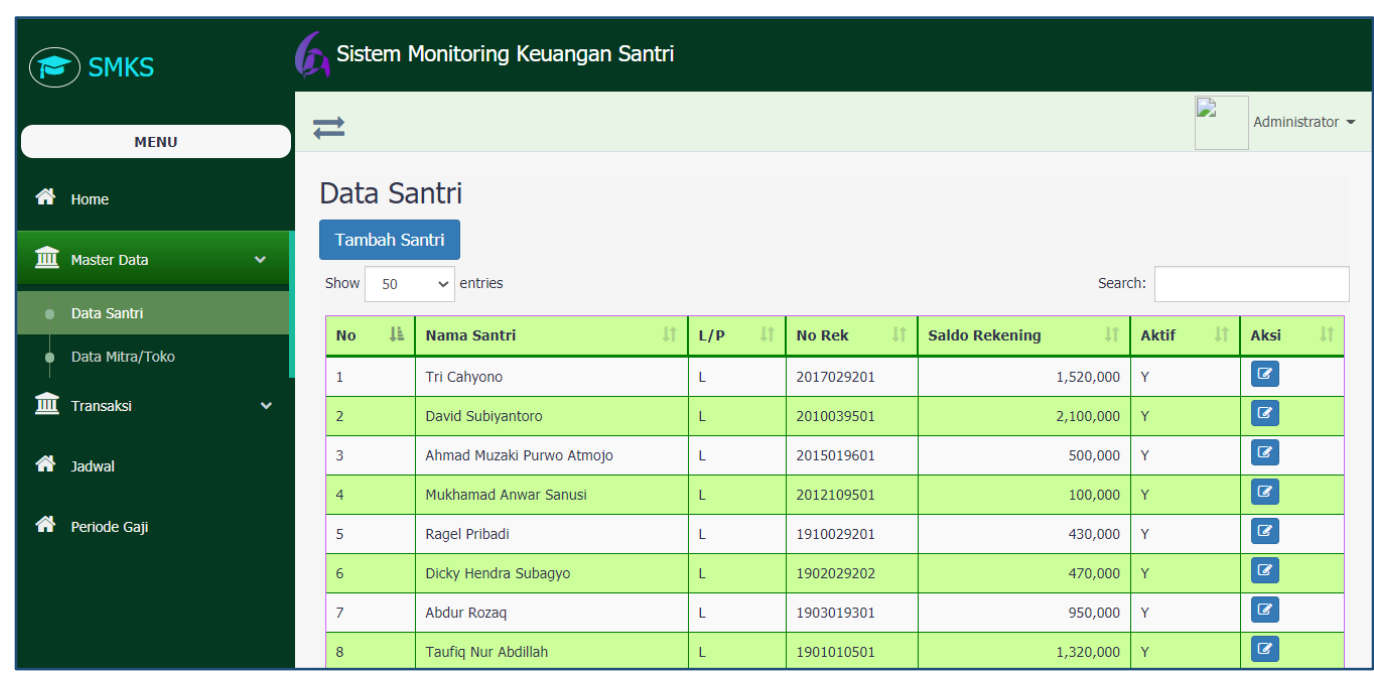

Gambar 4 : Tampilan halaman data santri

Untuk menambah data klik tombol tambah santri, sedangkan untuk edit data klik tombol pada kolom aksi. Form untuk input maupu edit data santri ditunjukkan pada gambar di bawah ini.

3. Halaman Cek Saldo dan Ubah Pin

\subsection{Halaman Cek Saldo}

Halaman ini digunakan untuk mudahkan santri dalam melakukan cek saldo rekening santri.

Melalu pengecekan saldo santri dapat mengetahui kondisi keuangannya yang ada di rekening. Sehingga mereka dapat merencanakan pengeluaran yang lebih baik. 


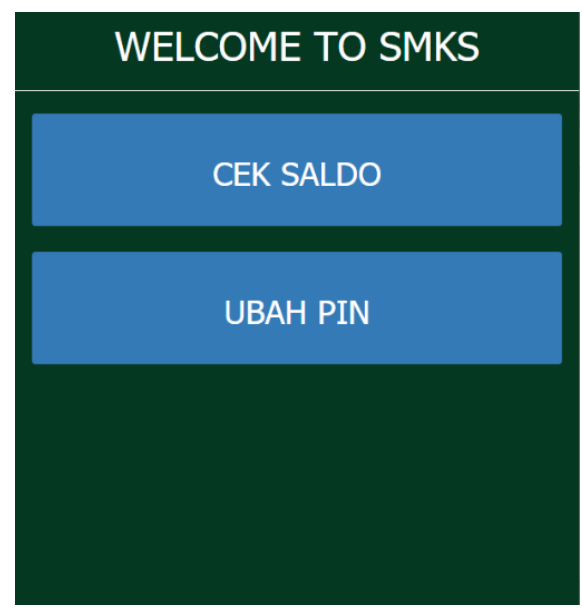

Gambar 5 : Tampilan halaman awal cek saldo dan ubah pin

Tombol Cek Saldo digunakan untuk masuk ke halaman CEK SALDO dan tombol UBAH PIN digunakan untuk masuk ke halaman perubahan pin. Pada halaman cek saldo diawali dengan perintah Silahkan Tap Kartu. Tap Kartu adalah proses menempelkan atau mendekatkan kartu RFID ke reader yang ada pada smartphone. Setelah kartu ditempel ke reader RFID aplikasi akan melakukan request data saldo berdasarkan nomor kartu tersebut ke server. Hasil informasi saldo akan ditampilkan seperti gambar di bawah ini.
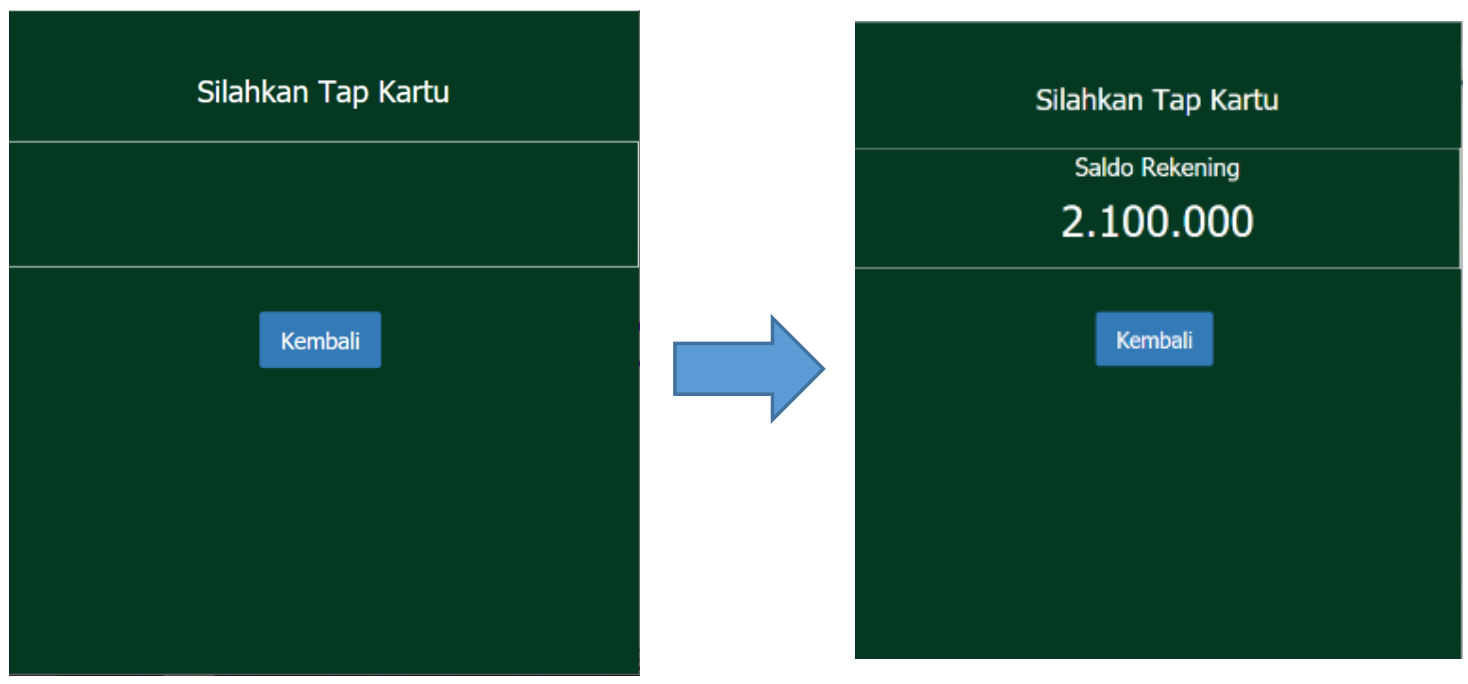

Gambar 6 : Tampilan halaman cek saldo

\subsection{Halaman Ganti Pin}

Halaman ganti pin digunakan untuk mengganti pin kartu rfid dalam rangka meningkatkan keamanan. Pin wajib diisi sebanyak 6 digit oleh pengguna. cara mengganti pin diawali dengan mendekatkan kartu rfid ke reader, lalu sistem akan melakukan pengecekan identitas dari kartu tersebut. Apabila kartu rfid teridentifikasi langkah berikutnya adalah memasukkan pin lama dan pin baru lalu tekan tombol GANTI PIN. Pin lama dan pin baru yang diinputkan akan dilakukan query oleh server, jika pin lama dan pin baru sudah sesuai makan akan muncul tulisan PIN BERHASIL DIGANTI. 

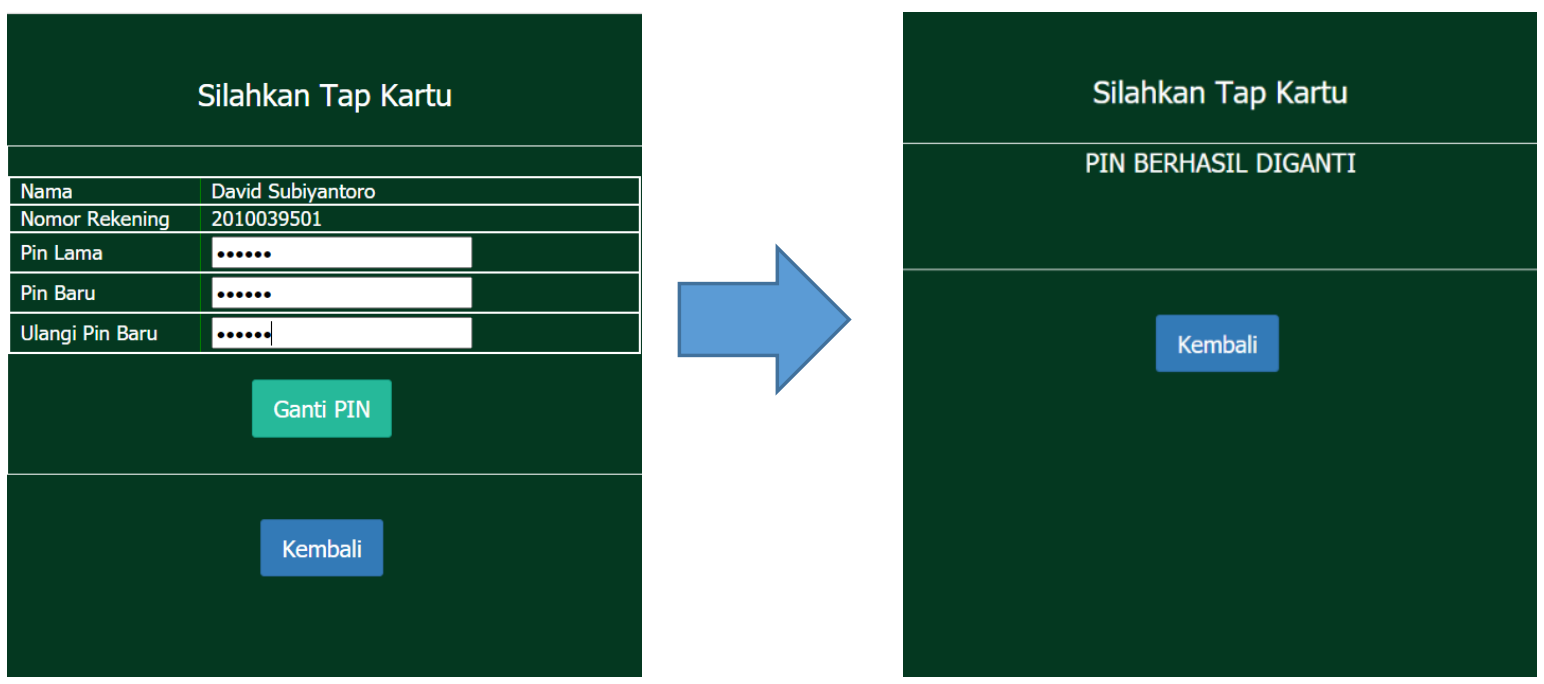

Gambar 7 : Tampilan halaman ganti pin

4. Halaman Toko / Mitra

Halaman ini digunakan oleh Toko / Mitra yang telah bekerjasama dengan pihak pesantren. Halaman ini terdiri dari:

4.1 Halaman Login dan Home

Halaman login digunakan untuk autentifikasi user yang merupakan bagian dari keamanan sistem, halaman home berisi menu PEMBAYARAN untuk melakukan pembayaran santri, HISTORY untuk melihat data transaksi, SET PASSWORD untuk mengganti password user dan LOGOUT untuk keluar dari sistem.

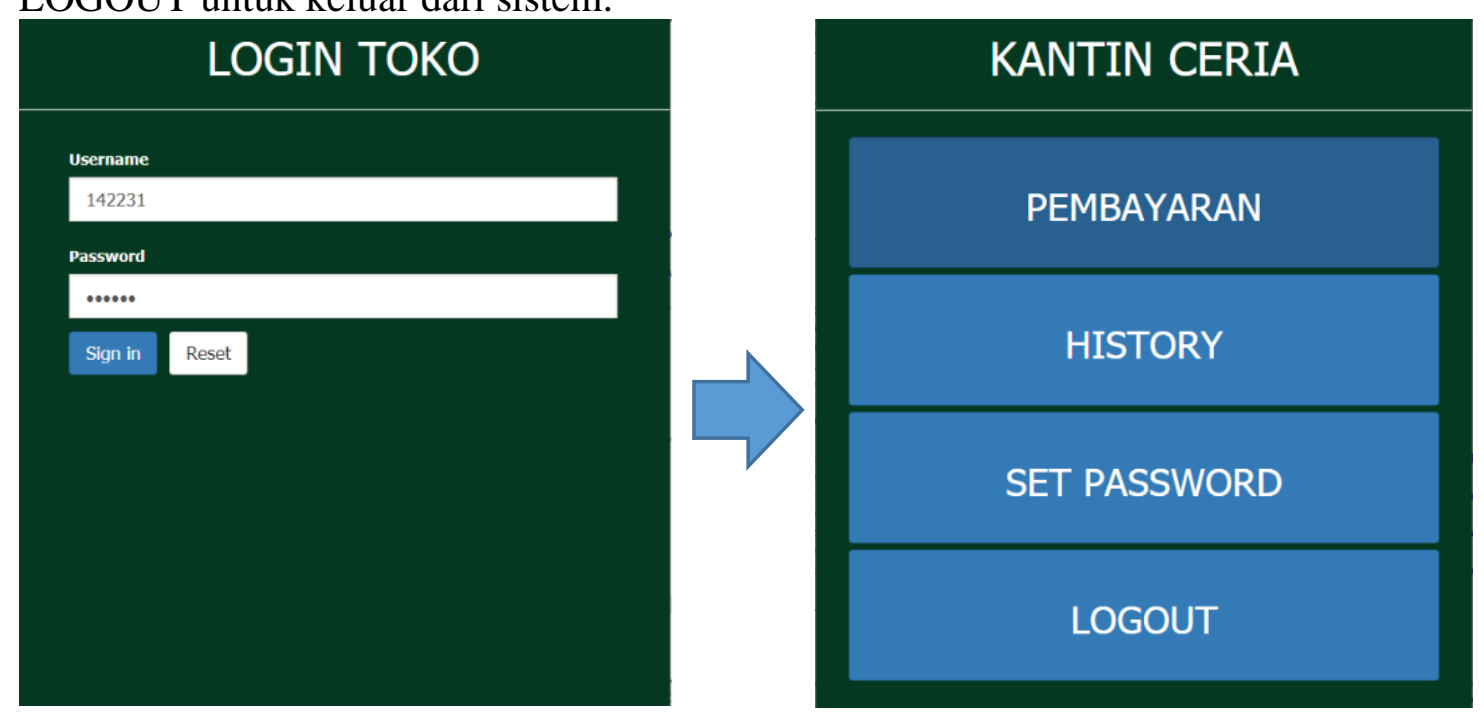

Gambar 8 : Tampilan halaman login dan home pada akun toko / mitra

Untuk masuk halaman login seperti gambar 10 (kiri), dilakukan dengan memasukkan username dan password yang diperoleh dari pihak admin. Setelah login akan muncul halaman home seperti pada gambar 10 (kanan). 


\subsection{Halaman Pembayaran}

Halaman pembayaran merupakan halaman untuk transaksi pembayaran yang dilakukan oleh santri setelah membeli barang / makanan pada toko / kios yang telah bekerjasama dengan pesantren. Langkah pertama pada saat pembayaran pemilik toko menghitung dan memasukkan total pembelian yang akan dibayar pada layar smartphone (lihat gambar 9).
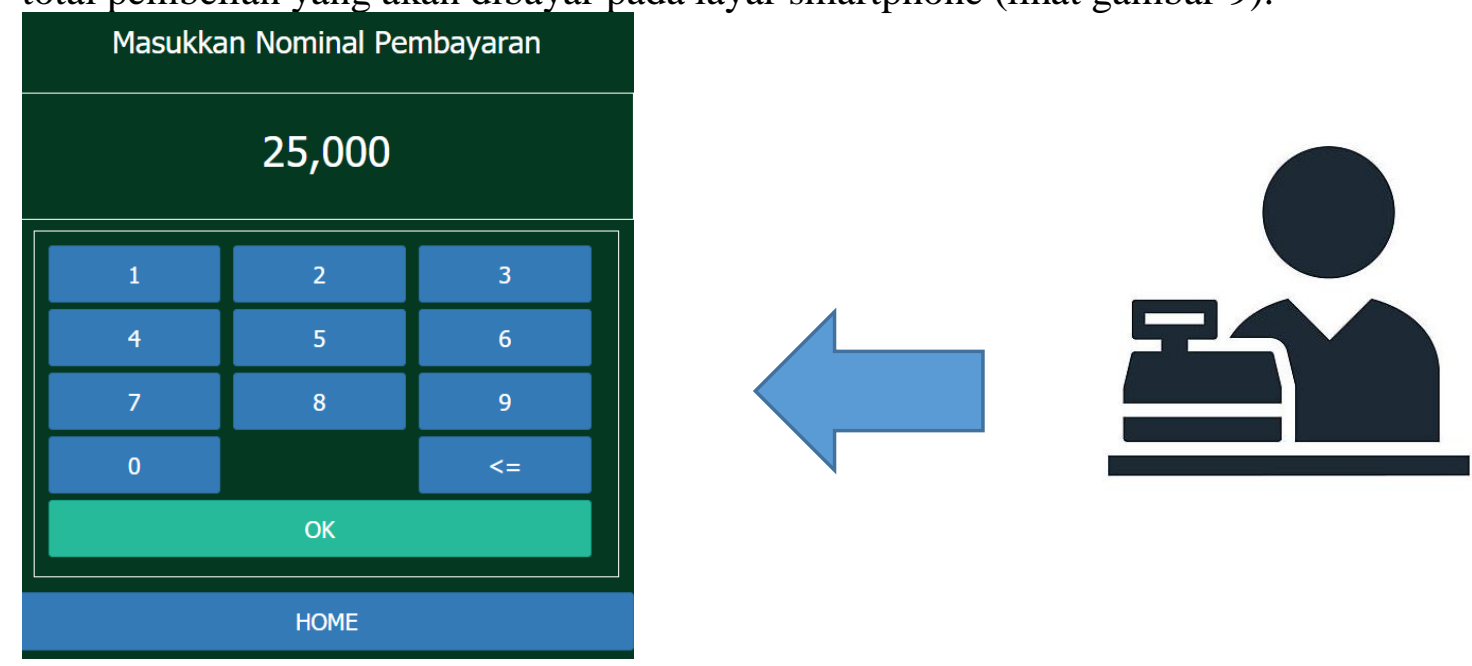

Gambar 9 : Tampilan halaman input nominal pembayaran oleh kasir/pemilik toko

Setelah kasir / pemiliki toko memasukkan nominal pembayaran kemudian santri melakukan tapping kartu RFID ke reader dan memasukkan pin kartu tersebut (gambar 12 kiri). Setelah klik tombol OK, sistem akan memproses transaksi dengan melakukan validasi id kartu dan pin yang telah dimasukkan. Transaksi yang berhasil diproses akan ditampilkan di layar berupa pesan berhasil (gambar 12 kanan).
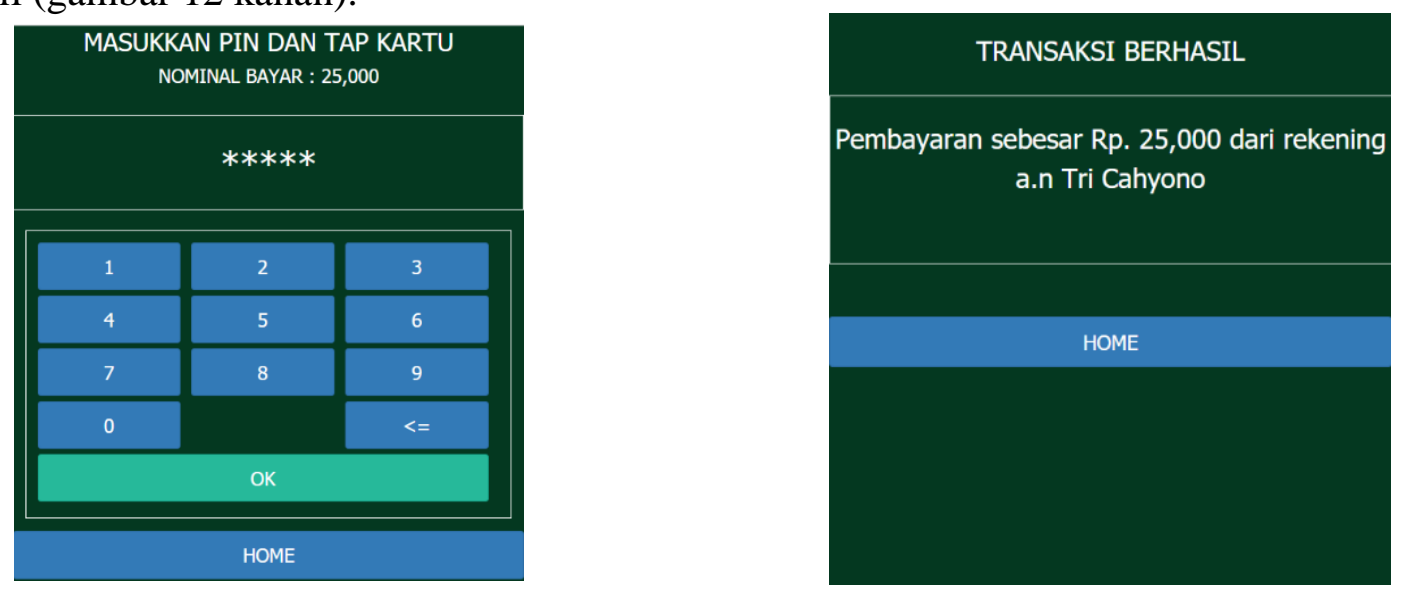

Gambar 10 : Tampilan halaman tap kartu dan input pin dan tampilan halaman transaksi berhasil

Data transaksi yang diproses pada halaman pembayaran akan mengurangi saldo pada rekening santri dan akan menambah saldo pada rekening pemilik toko. Apabila pada saat transaksi pembayaran saldo rekening santri tidak mencukupi atau pengeluaran harian sudah melebih batas yang ditentukan akan muncul pesan transaksi gagal, saldo tidak mencukupi. Begitu juga apabila terjadi kesalahan pada saat menginputkan pin akan muncul pesan gagal, pin invalid (lihat gambar 11). 

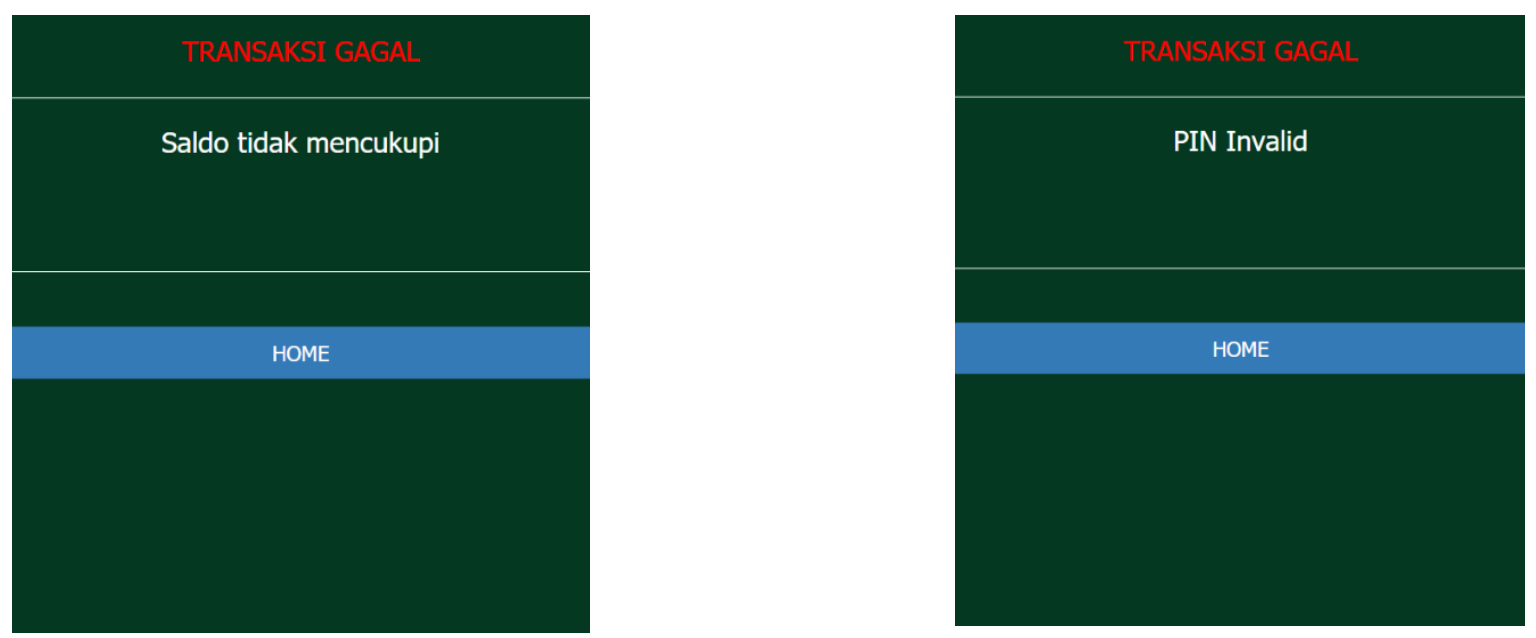

Gambar 11 : Tampilan halaman kegagalan transaksi pembayaran

\section{HASIL PENGUJIAN}

Hasil penelitian ini dilakukan pengujian lapangan berupa simulasi atau uji coba terbatas. Pengujian ini difokuskan pada pembacaan RFID pada halaman cek saldo, ganti pin dan transaksi pembayaran. Tujuan pengujian ini untuk mengetahui apakah software yang telah dibuat telah sesuai dengan perancangan baik alur, kemampuan peripheral maupun pemrosesan datanya dengan menghitung waktu respon yang dibutuhkan untuk masing-masing proses. Pengujian ini menggunakan 1 smartphone dilengkapi dengan RFID reader serta menggunakan kartu / tag RFID pasif sebanyanyak 20 buah.

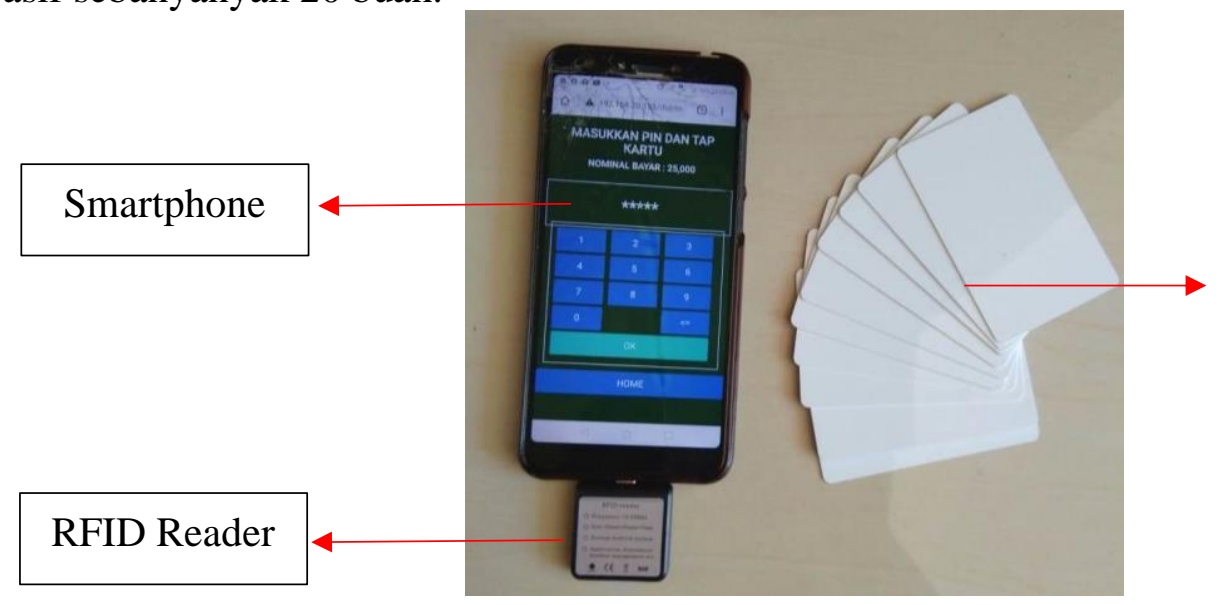

Tag RFID berbentuk kartu

Hasil pengujian dapat dilihat pada tabel di bawah ini.

Tabel 1 : Hasil pengujian sistem

\begin{tabular}{|c|c|c|c|c|c|}
\hline \multirow[b]{2}{*}{ No } & \multirow[b]{2}{*}{ Nama } & \multirow[b]{2}{*}{ No Card (RFID) } & Cek Saldo & Ganti Pin & Pembayaran \\
\hline & & & respon time (s) & respon time $(\mathrm{s})$ & respon time $(\mathrm{s})$ \\
\hline 1 & Tri Cahyono & 2576819961 & 1 & 12 & 4 \\
\hline 2 & David Subiyantoro & 2549242441 & 2 & 12 & 5 \\
\hline 3 & Ahmad Muzaki Purwo Atmojo & 2576865577 & 1 & 9 & 4 \\
\hline 4 & Mukhamad Anwar Sanusi & 2577373273 & 1 & 11 & 5 \\
\hline
\end{tabular}




\begin{tabular}{rlcccc}
\hline 5 & Ragel Pribadi & 2577633801 & 2 & 8 & 5.5 \\
\hline 6 & Dicky Hendra Subagyo & 2577681353 & 3 & 11 & 4.5 \\
\hline 7 & Abdur Rozaq & 2577203721 & 1 & 8 & 4 \\
\hline 8 & Taufiq Nur Abdillah & 2576845977 & 2 & 11 & 5 \\
\hline 9 & Iqbal Bayu Rizqi & 2576882137 & 1 & 10 & 5 \\
\hline 10 & R. ABDULLAH HAMMAMI & 2576689465 & 3 & 11 & 4 \\
\hline 11 & Chaiz Azizil Amani & 2576686462 & 2 & 11 & 5 \\
\hline 12 & Syafri Al Hilmy & 2576699461 & 2 & 10 & 5 \\
\hline 13 & Hamdani Lubis & 2576619415 & 1 & 11 & 4 \\
\hline 14 & Febrian Dwi Putra & 2576589425 & 1 & 11 & 5.5 \\
\hline 15 & Muh. Amak Syamsudin & 2576687460 & 1 & 9 & 4 \\
\hline 16 & Moh. David Azmi & 2576689125 & 1 & 9 & 5.5 \\
\hline 17 & Alex Sukoco & 2576689123 & 1.5 & 10 & 4 \\
\hline 18 & Ali Mushthofa & 2576689856 & 1 & 9 & 5.5 \\
\hline 19 & Ahmad Setiyoko Ali syaifullah & 2576689945 & 1.5 & 9 & 4 \\
\hline 20 & Zainal Asrofi & 2576689219 & 2 & 9 & 5 \\
\cline { 3 - 6 } & & & & & 4 \\
& & & & & 4.05 \\
\hline
\end{tabular}

Hasil pengujian di atas menunjukkan rata-rata waktu yang dibutuhkan proses cek saldo adalah 1.55 detik, pada proses pergantian pin membutuhkan waktu rata-rata 10.05 detik dan pada proses pembayaran membutuhkan waktu rata-rata 4.675 detik. Pada proses cek saldo memperoleh waktu tercepat karena tahapan prosesnya hanya satu yaitu menempelkan kartu RFID ke reader, sedangkan waktu yang dibutuhkan paling lama adalah proses pergantian pin karena harus melalui tahap menempelkan kartu rfid, memasukkan pin lama dan memasukkan pin baru sebanyak dua kali. Pada proses pembayaran dibutuhkan waktu rata-rata 4.675 detik dengan proeses menempelkan kartu RFID ke reader lalu menginputkan pin.

\section{KESIMPULAN}

Penggunaan RFID sebagai sebagai alat pembayaran memiliki peran seperti ATM pada umumnya. Penggunaan RFID lebih simple karena proses penggunaannya hanya dengan mendekatkan atau menempel kartu ke sensor readernya. Penggunaan RFID pada penelitian ini digunakan dalam lingkungan sekala kecil yaitu lingkungan pondok pesantren. Hasil pengujian didasarkan pada proses cek saldo yang rata-rata prosesnya membutuhkan waktu 1.55 detik, proses pergantian pin rata-rata 10.05 detik proses pembayaran membutuhkan waktu rata-rata 4.675 detik. Melalui sistem yang telah dibuat pada penelitian ini, pihak pondok pesantren dapat mengontrol keuangan santri melalui halaman untuk admin serta penerapan pembatasan pengeluaran santri setiap harinya pada sistem tersebut, sehingga meskipun santri memiliki saldo yang banyak pada rekeningnya, tetapi pengeluaran tetap dibatasi, hal ini untuk mencegah pemborosan santri dalam membelanjakan uangnya.

Saran dan rekomendasi yang dapat diberikan penulis bagi pembaca maupun peneliti lainnya, untuk melakukan penelitian lanjutan berkaitan dengan penelitian ini adalah mengembangkan sistem yang lebih luas seperti bekerjasama dengan bank untuk pembuatan pembayaran virtual account sehingga orang tua yang akan melakukan pengiriman uang ke anaknya dapat langsung melalui transfer dan otomatis.

\section{UCAPAN TERIMAKASIH}

Ucapan terima kasih kami sampaikan kepada seluruh pihak yang telah membantu selesainya penelitian ini, terutama kepada Kemenristek/Brin yang telah mendanai penelitian ini mulai awal hingga akhir. 


\section{DAFTAR PUSTAKA}

1. Alien Technology (n.d.). ALR-9900 Enterprise RFID Reader. Diakses pada 30 April, 2019, di http://www.alientechnology.com/wp-content/uploads/Alien-Technology-ALR-9900-EnterpriseRFIDReader.pdf

2. Charles P M Siahaan, Fakhruddin Rizal B, 2014, "Perancangan Sistem Pembayaran Parkir Secara Otomatis Menggunakan RFID (Radio Frequency Identification"), Jurnal Singunda Ensikom Universitas Sumatera Utara (USU), VOL. 9 NO. 3, Desember 2014.

3. Duroc, Y., \& Tedjini, S. (2018). RFID: A key technology for Humanity. Comptes Rendus Physique, 19(1-2), 64-71. https://doi.org/10.1016/j.crhy.2018.01.003

4. Hanif Al Fatta., 2007, Analisis \& Perancangan Sistem Informasi Untuk Keunggulan Bersaing Perusahaan \& Organisasi Modern, ANDI Offset, Yogyakarta

5. Henky Vasko P. Manalu, Seno D. Panjaitan, Nielcy T. Mooniarsih, 2015, "Perancangan Sistem Pembayaran Berbasis Radio Frequency Identification (RFID) Pada Food Court", Jurnal Teknik Elektro Universitas Tanjungpura Vol 2, No 1.

6. Muhammad Ilyas Prakananda, 2012, "Rancangan Penerapan Teknologi RFID Untuk Mendukung Proses Identifikasi Dokumen Kendaraan Di Samsat", Prosiding Seminar Nasional Aplikasi Sains \& Teknologi (SNAST), Periode III, ISSN: 1979-911X, Yogyakarta, 3 November 2012.

7. O’Brian, James A., 2005, Pengantar Sistem Informasi Perspektif Bisnis dan Manajerial, McGraw-Hill Irwin, Edisi 12, Salemba Empat, Jakarta

8. Samuel Aditya Utomo, Darmawan Utomo, Banu Wirawan Yohanes, 2016, "Sistem EMoney berbasis Contactless Smartcard dengan Teknologi RFID”, Techné Jurnal Ilmiah Elektroteknika Vol. 15 No. 1 April 2016 Hal 67-75.

9. S. Piramuthu, S. Wochner, M. Grunow, Should retail stores also RFID-tag 'cheap' items? Eur. J. Oper. Res. 233 (2014) 281-291.

10. Sukmadinata, Nana Syaodih. 2013. Metode Penelitian Pendidikan. Bandung : PT Remaja Rosdakarya.

11. Suryadiputra Liawatimena, 2010, “Analisis Dan Perancangan Sistem Karcis Elektronik Pada Gerbang Masuk Busway Dengan Menggunakan RFID”, ComTech Vol.1 No.2 Desember 2010 Hal 942-955. 